\title{
PRACTICAL APPLICATION OF THE CONCEPT OF SEPARATING THE ZONE OF OVERHEATING AND REDUCING THE STRESS LEVEL IN CATHODE BLOCK OF AN ALUMINIUM ELECTROLYTIC CELL DURING FORMATION OF CONNECTION WITH THE STEEL PIN BY CAST IRON POURING
}

\begin{abstract}
The article presents the concept of division of a carbon block into single cathode sections to reduce stresses that occur during thermal shock accompanying the operation of pouring cast iron into a shaped groove in which the current-carrying steel pin is mounted. The temperature field and the state of stress were determined by FEM. Experimental measurements were used to determine the core displacement during pouring operation. The calculations were verified by thermovision and photoelastic method. Based on the temperature field and stress field analysis, a method for the block division into sections has been proposed, resulting in a significant reduction of the stress level.

Keywords: aluminium electrolytic cell, cathode section, cast iron, FEM calculations
\end{abstract}

\section{Introduction}

The stress field arising in the carbon block of cathode section when a connection is made between the steel pin and the surface of a shaped groove in the block is caused by the effect exerted on both components of the connection by a variable field of temperature, the source of which is heat provided by the cooling down and solidifying casting. The temperature field is responsible for a distortion of the carbon block and the steel pin, an immediate consequence of which is the formation of angular and edge cracks in the section. The state of stress in the carbon block is the sum of thermal stresses present in the block and mechanical stresses caused by the pin movement in the shaped groove under the influence of temperature field varying in time. Based on the analysis of thermal and mechanical loads in the carbon block it is possible to determine and identify the methods which will reduce the stress level by:

- reducing the magnitude of pin deflection,

- $\quad$ reducing the level of thermal stress in carbon block.

These methods can be implemented using the criteria of the strength-based shaping of design allowing for changes in the structure geometry, the selection of materials with thermal and mechanical properties favouring the stress level reduction, and changing the technique of pouring the shaped groove with cast iron. For a more detailed analysis it is necessary to determine the temperature field, the stress field and the displacement in the section when the connection is being made. The thermal stresses caused by an unsteady heat flow can be specified more precisely as:

- $\quad$ strain-controlled thermal stresses in the case of which the local expansion or contraction of material is constrained by the adjacent layers of this material,

- displacement-controlled thermal stresses in the case of which the expansion or contraction of each element of the structure is constrained by other elements.

Stresses of the first type correspond to a free bending of the block and depend on the temperature gradient. They can be reduced by reducing the magnitude of the gradient, which in the case of a cathode section means reducing to the lowest possible level the temperature of pouring and keeping relatively high temperature of the section preheating. However, the possibilities of changing the temperature of both pouring and preheating are rather limited due to the impact that these two parameters have on the process of making the cathode section. The displacementcontrolled stresses appear when the object has limited possibility of free bending and they increase with the increasing dimensions of the object. Stresses of this type can also be reduced by reducing the temperature gradient and by partial release of the constraints to let the individual parts of the design undergo free bending or elongation. This solution is possible by selecting from the entire design the components whose expansion is not constrained or is constrained to a much lesser extent only by other components. The concept which parts of the structure should be selected is based on the results of an analysis of the 
state of stress or temperature field. The analysis of the state of stress determines the causes and the places where stresses can assume the extreme values. Based on this analysis it is possible to determine which parts of the structure should be allowed to undergo the free deflection to reduce stresses and to obtain their distribution favourable in respect of the strength values. In terms of the temperature field, the concept of making the division can use the run of isothermal lines showing areas with large temperature gradients, zones overheated to a certain temperature (the depth of the overheated zone) and those where the temperature remains basically unchanged. It is also possible to indicate these parts using our knowledge of temperature-related changes in the mechanical and thermal properties of the tested material. It seems that studies should cover both temperature field and the state of stress, as only then we can get a complete set of information, based on which the division of the structure can be made, impossible when only one of these parameteres is examined. At this point it also seems appropriate to try to systematize various methods leading to the stress reduction in a cathode section.

In short, the level of stress can be reduced by:

- reducing the elongation of the steel pin which can be achieved by changes introduced to the technology of making the connection,

- $\quad$ strength-based shaping of the carbon block.

In turn, the strength-based shaping of the block can be achieved through the analysis of:

a. temperature field and determination of the critical value of:

- isothermal line,

- temperature gradient,

- the depth of the zone of overheating,

- the isothermal line characteristic of these material properties that influence the strength of the carbon block,

b. stress field and determination of:

- those parts of the structure which require changes in the number of the degrees of freedom,

- the possibility to reduce the stress level by changing the geometry.

Below a concept is disclosed that is largely based on the above given points and relates to the division of carbon block into units allowing for the analysis of temperature field and stress field.

\section{Stress in the cathode section block induced by thermal shock}

Numerical calculations by finite element method were performed using an ABAQUS software. For the discretization of a spatial model of the cathode section, the eight-node linear elements were applied. This model was used to analyze the temperature field, the displacement and the state of stress, all of which occur during pouring and cooling of cast iron in a shaped groove. The calculations allowed for an impact of temperature changes on the value of specific heat, thermal conductivity, density, coefficient of linear expansion and modulus of elastic- ity of the carbon material, cast iron and steel. The anisotropy of carbon material was also taken into account by varying the above-mentioned thermal and mechanical properties along the long axis of the block and in the direction perpendicular thereto, resulting from the technology adopted in the block formation [6-10]. Both temperature field and the state of stress in carbon block change in time during cooling of cast iron in the shaped groove. The maximum tensile stresses in the zone of edge cracks occur after approximately 380 seconds since the time instant of filling the groove with cast iron and amount to about $2 \mathrm{MPa}$ (Fig. 1). In turn, the maximum tensile stresses in the zone of angular cracks amount to approximately $3.8 \mathrm{MPa}$ and occur after the lapse of 30 seconds.

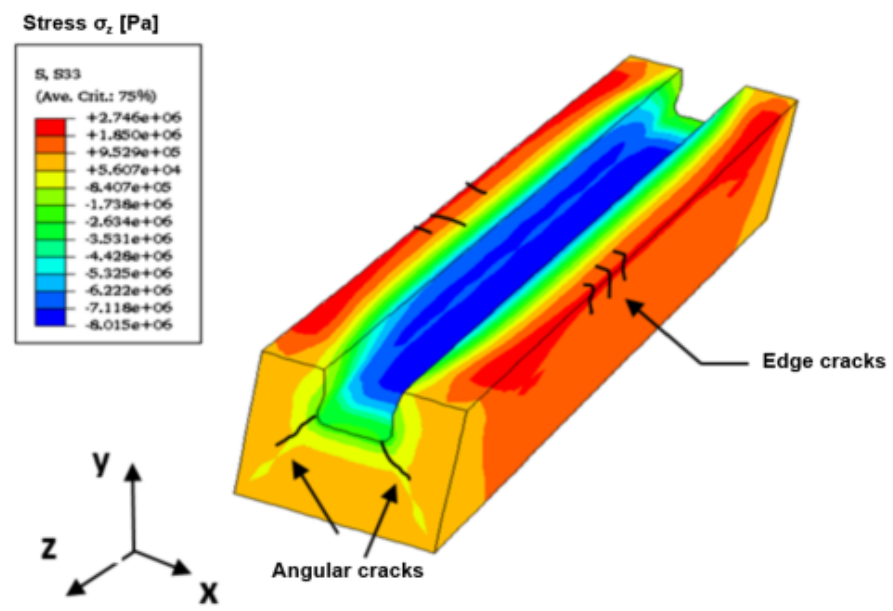

Fig. 1. Stress field $s_{z}$ that occurs in carbon block after the lapse of 380 seconds since the time instant of filling the shaped groove with cast iron.

Due to the heterogeneity of carbon material and deviations from the established technological regime of making the connection, the calculated numerical values of stresses can result in the initiation of cracks which will propagate during operation of the cell.

\section{The concept of partitioning the carbon block into sections}

As mentioned previously, pouring of the shaped groove with cast iron raises in the carbon block a non-linear temperature field varying in time. Due to the limited amount of heat delivered by the cooling down cast iron and heat exchange going on between the heated carbon block and the environment, only the area adjacent to the surface of the shaped groove will absorb large volumes of the heat. The idea of dividing the structure according to the calculated depth of the zone of overheating is based on the position of the previously selected isotherm, whose value during thermal contact between the cast iron and carbon block will either remain constant or will be varying in a pre-assumed range of values. The analysis of temperature changes in the carbon block cross-section at varying distances from the surface of the shaped groove (Fig. 2) clearly shows 
the area where the temperature increase above $T_{N}=400^{\circ} \mathrm{C}$ is negligible. Assuming now that the permissible temperature range (the width of the isothermal line) should not exceed $50^{\circ} \mathrm{C}$, the line of the division will run parallel to the contour of the shaped groove at a distance of about $85 \mathrm{~mm}$ (Fig. 2, the plotted curve of temperature changes no. 5)

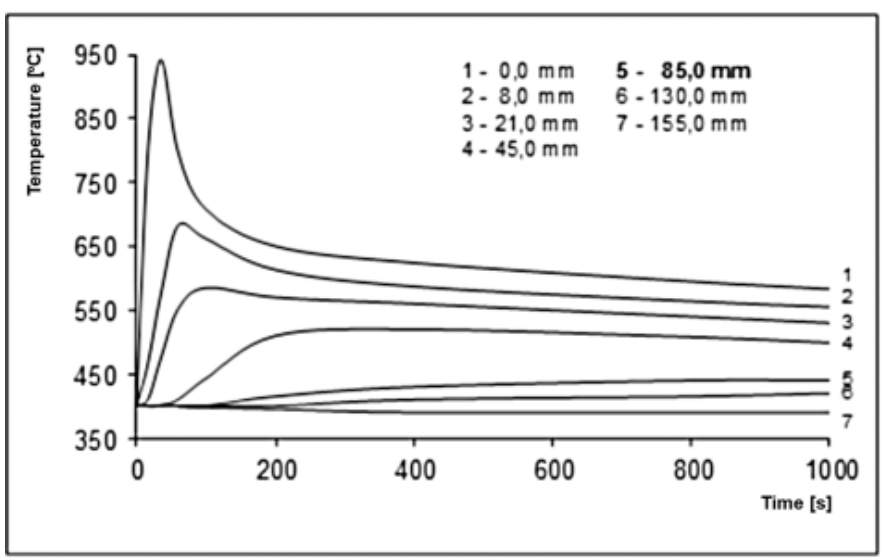

Fig. 2. Temperature changes in the cross-section of carbon block at different distances from the surface of the shaped groove.

As mentioned earlier, the decisive influence on the crack formation in the block has the duration of the thermal shock. Fig. 3 shows temperature changes in the cross-section of a side wall of the block at a critical moment when the temperature of the shaped groove surface reaches its maximum and, at the same time, the difference between the temperature of the shaped groove surface and outer surface also reaches its maximum. From the shape of the curve (Fig. 3) it can be assumed that the division of the block into elements should run parallel to the contour of the groove at a distance of about 40 to $45 \mathrm{~mm}$. At that distance is running the isothermal line of $400^{\circ} \mathrm{C}$ making division between the areas with the temperature higher and lower than the starting temperature of the block.

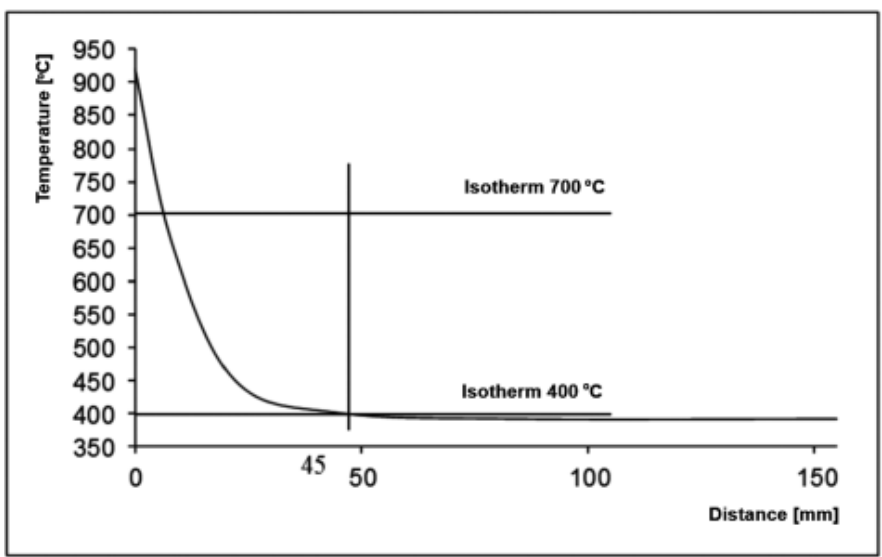

Fig. 3. Temperature changes in the cross-section of a side wall of the block during thermal shock

Another temperature-related criterion, which can serve as a basis for the division of structure into separate elements, is the location of an isothermal line characteristic of the selected material property which determines the strength of the structure. In the case of the examined carbon block, very important are temperature-related changes in the coefficient of linear expansion, which has a significant impact on the magnitude of stress. On the curve of changes in the coefficient of linear expansion, two intervals separated by the temperature of approx. $700^{\circ} \mathrm{C}$ are distinguished. Above this temperature, the value of the coefficient remains nearly unchanged, while below $700^{\circ} \mathrm{C}$ it shows a much faster decline. The location of the isothermal line of $700^{\circ} \mathrm{C}$ at the time of the thermal shock occurrence is indicated in Fig. 3. As can be seen, it is running at a distance of approximately $8 \mathrm{~mm}$ from the plane of the shaped groove. The choice of a criterion which will be used in the division of the structure must also take into account the manufacturability factor that eliminates some of the possible ways to divide the structure and requires sufficient thickness of the item. One of the possible solutions of making the division is shown in Fig. 4.

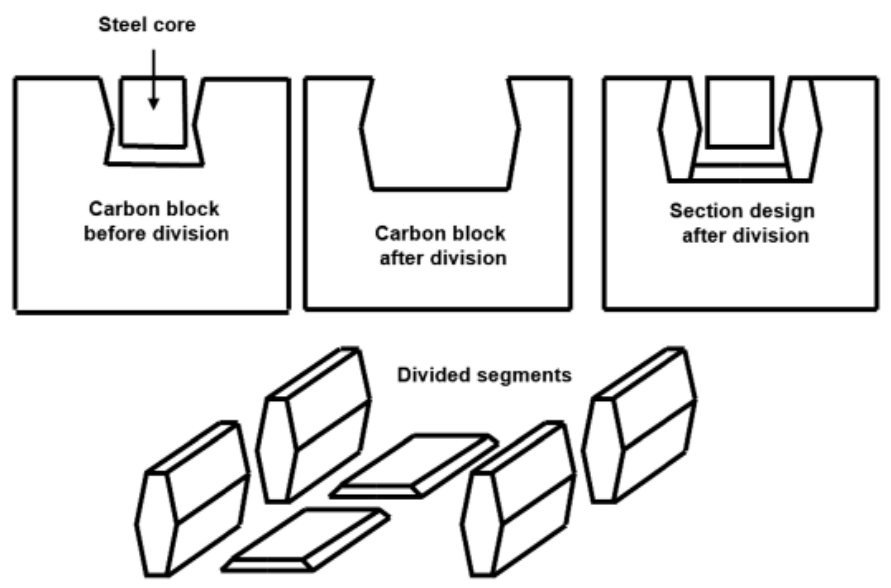

Fig. 4. A way to divide the structure of a carbon block

This solution involves making a relatively large throughhole in the original carbon block and introducing relevant segments into thus formed cavity. The shape of the segments ensures their manufacturability and ease of attachment. Based on the analysis of thermal and mechanical properties of carbon materials it is possible to select an optimum material for the individual elements of the section. It should be noted that the dedicated segments are subjected to the direct impact of molten cast iron, and therefore certain phenomena caused by the thermal shock are expected to take place in their volume. In the family of carbon materials, it is graphite that exhibits the strength and thermal resistance superior to the conventional materials. Using the difference in the expansion of graphite and anthracite covering one order of values, it becomes possible to further reduce stresses in the block structure divided into segments (Fig. 4). In this case, the separate segments are to be made of graphite or graphitized material, while monolithic part of the block should be made of an amorphous material. Under the influence of temperature, changes in the dimensions of graphite segments with a lower coefficient of thermal expansion will not be hampered by 
the monolithic block made from the material with a higher coefficient of thermal expansion, ultimately resulting in a reduced level of stress.

\section{The state of stress in a converted structure of the carbon block}

The proposed changes in the design were included in a numerical model of the cathode section. Additionally, to verify the calculations and compare the state of stress in a onventional design of the block with the state of stress in a modified design, experimental studies were carried out using thermovision and photoelastic method.
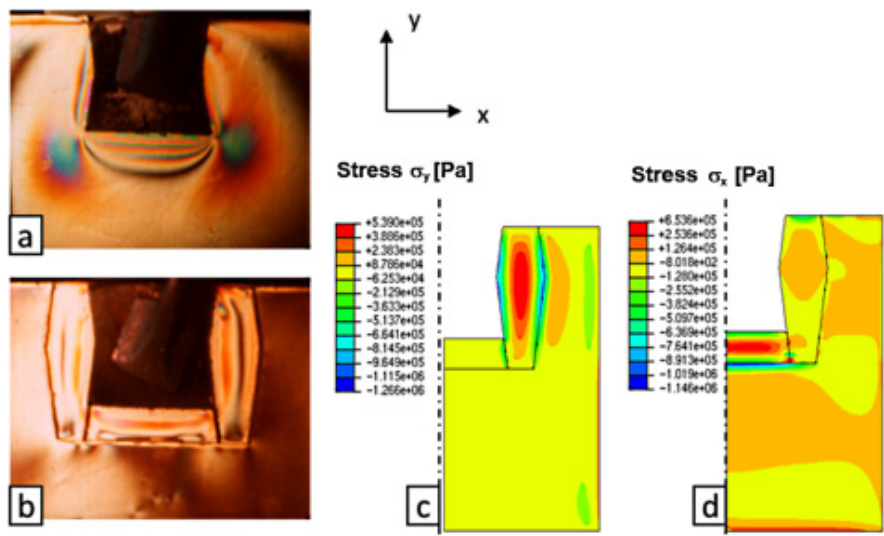

Fig. 5. Stresses visible in the zone of angular cracks after the lapse of 30 seconds since the time instant of filling the shaped groove with cast iron; $\mathrm{a}$ - the original design; elasto-optic image $\mathrm{y}, \mathrm{b}$ - the design after modifications; elasto-optic image, $\mathrm{c}, \mathrm{d}$ - the design after modifications; numerical calculations

Flat models of the block cross-sections cut out from epoxy boards were placed between the quartz glass panes and then heated with liquid, low-melting point alloy. These studies provided information about the changing state of stress in both structures under the influence of sudden temperature rise on the edge of the shaped groove and confirmed that the selected segments were the main ones to carry the highest thermal loads, while other parts of the block have remained virtually stressfree. In solid structure not divided into separate parts, the effect of thermal shock was observed to cause much higher stresses in the zone adjacent to the shaped groove. A comparison of the state of stress was possible examining the images of isochromes shown as an example in Figure 5a,b. The preceding examples of calculations and analysis of the results show that the proposed structural changes have led to a significant reduction in the stress value. The maximum stress value was reduced almost ten times to about $0.5 \mathrm{MPa}$ (Fig. 5c, d). This value is sufficiently low to make the risk of crack formation due to excessive thermal loads much less probable than in a monolithic block. Even if, despite the changes introduced, cracks did form in the material, they would not propagate throughout the entire block and would not result in breaking off and detachment of its upper part, but would be arrested at the contact plane between selected fragments of the block and the remaining monolithic body. Owing to this, failures of electrolytic cells due to liquid aluminium penetration through the carbon liner would be eliminated.

\section{Verification of numerical model}

It has been assumed that the correctness of the results obtained using a numerical model will be confirmed by measurements of the steel pin deflection during pouring and cooling of cast iron in the shaped groove. Measurements were taken several times stating differences in the obtained values of displacement. Changes in the displacement of the pin measured experimentally and calculated numerically are shown in Fig. 6.

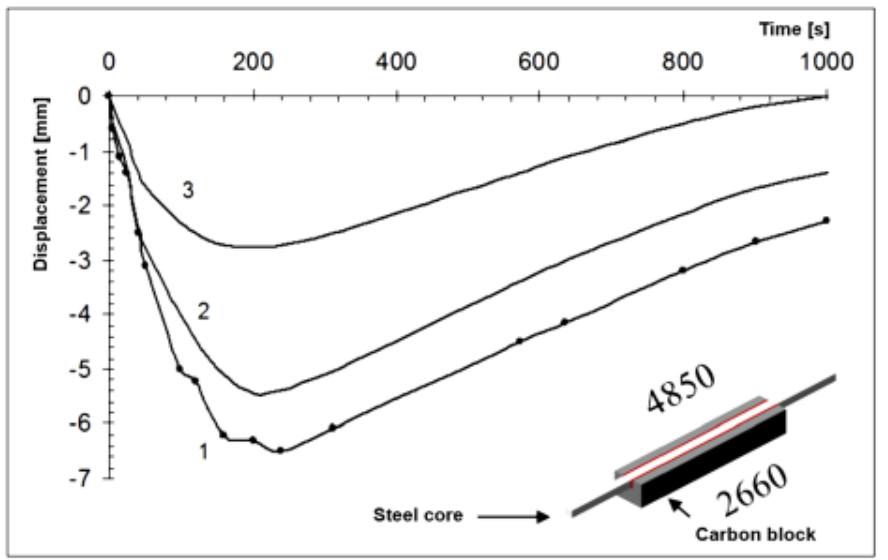

Fig. 6. Changes in the displacement of pin ends during cooling of cast iron in the shaped groove examined for the section preheated to a temperature of $T_{N}=200^{\circ} \mathrm{C}$ and $T_{N}=350^{\circ} \mathrm{C} ; 1-$ the displacement determined empirically for $T_{N}=200^{\circ} \mathrm{C}, 2$ - the displacement determined numerically for $T_{N}=200^{\circ} \mathrm{C}, 3$ - the displacement determined empirically for $T_{N}=350^{\circ} \mathrm{C}$.

Three techniques of pouring the shaped groove are used most frequently:

- direct pouring of metal from a ladle into the shaped groove of carbon block,

- $\quad$ pouring with the use of pouring basin acting at the same time as a spray gating system,

- $\quad$ pouring in segments according to a certain pattern.

In all these cases, the metal is fed into a space between the block and the pin. In this technique of pouring, the hot metal is heating most strongly the lower part of the pin and its side walls as the cast iron column is rising filling the free space in the groove. The upper surface of the pin has the lowest temperature, which makes its ends curve up. In the case under discussion a different method of pouring was used, namely the metal was fed directly to the upper surface of the core. The change in the pouring technique made the pin ends bend in the direction opposite to that experienced in the commonly applied method of pouring. The opposite direction of bending has eliminated gaps at the ends of the block and prevented excessive movements of the 
pin relative to the block, which could cause cracks. A good agreement was found between the values of the steel pin displacement measured experimentally and calculated numerically (Fig. 6).

\section{Summary}

Due to the high strength and low electrical resistance of connection, the most common method of joining together the carbon block and the steel pin forming a cathode section is by pouring the free space in a groove with cast iron. When molten cast iron enters into contact with the surface of the shaped groove, the phenomenon of thermal shock occurs in the block, giving rise in some cases to the formation of cracks in this block. Using a relationship between the durability of a structure made from porous material and its dimensions, it can be concluded that when this type of material is used an attempt should be made to minimize the dimensions of the block or to develop a design composed of several separate parts. The method of making the division is based on the, calculated from temperature field, critical values of temperature gradient, the depth of the zone of overheating, the isothermal line separating the areas of the conventionally adopted different physical and chemical properties of the material, or it can use the analysis of the stress field and the effect that is exerted on the stress value by the number of the degrees of freedom changed in the design. The adopted mode of partitioning also depends on the manufacturability criterion that eliminates some of the possible ways of making the division. The division of the structure into parts that involves making a large through hole in the block and introducing appropriately shaped segments into it means that these segments are free to expand and capable of taking up a substantial portion of the thermal shock, while the monolithic body can be regarded as almost free of stress. In a monolithic structure the propagation of angular cracks can result in breaking off and detachment of the upper part of the block, while in the construction divided into segments the crack propagation will be arrested by the segment line of division, counteracting in this way the unsealing of the cell.

\section{REFERENCES}

[1] M. Sorlie, H.A. Oye, Cathodes in Aluminium Electrolysis, Aluminim-Verlag GmbH, Duesseldorf, 2010.
[2] B. Allard, D. Dumas, P. Lacroix, G. Fantozzi, D. Rouby, Fracture behaviour of carbon materials for aluminium smelters, Light Metals 749-758, (1991).

[3] B. Larsen, M. Sorlie, Stress analysis of cathode bottom blocks, Light Metals, 641-646, (1989).

[4] I. Letizia, C. Bizzarri, M. Lezzerini, How to improve the pig iron sealing of metallic bars, Light Metals, 1025-1036, (1985).

[5] L. Michard, Modelling of the sealing of cathode bars into carbon blocks, Light Metals 2, 699-704, (1986).

[6] J J. Piekło, Określenie kryteriów konstrukcyjnych dla połączenia stalowo-węglowego na przykładzie katody elektrolizera aluminium, PhD thesis, AGH, Kraków 2002.

[7] B. Allard, J.M. Dreyfus, M. Lenclud, Evolution of thermal, electrical and mechanical properties of graphitised cathode blocks for aluminium electrolysis cells with temperature, Light Metals, 641-645, (2004).

[8] Z. Shi, J. Xu, B. Ren, Y. Ban, Z. Wang, Tests of various graphitic cathode blocks material for $300 \mathrm{kA}$ aluminium reduction cells, Light Metals, 849-852, (2007).

[9] H. Oye, ISO standarts for testing of cathode materials, Light Metals, 937-942, (2008).

[10] A. Murchi, W. Chen, M. Tremblay, Comparative characterization of graphitized and graphitic cathode blocks, Light Metals, 617-624, (2003).

[11] Z. Orłoś, Naprężenia cieplne, PWN, Warszawa 1991, p. 107.

[12] J. Piekło, Experimental Investigation of the Stress Changes Induced by Thermal Shock in the Selected Cross-Sections of Birefrigent Models by Means of the Photoelastic and Thermovision Methods, Prace Instytutu Odlewnictwa, 2-3, 71-91, (1990).

[13] J. Piekło, Analiza odkształceń i naprężeń podczas krzepnięcia i stygnięcia odlewu na podstawie obliczeń numerycznych wykonanych z wykorzystaniem modułu MAGMAstress, Biuletyn Instytutu Odlewnictwa, 4, 25-31, (1999).

[14] K. Skoczowski, Technologia produkcji wyrobów węglowo-grafitowych, Śląskie Wydawnictwo Techniczne, Katowice 1995.

[15] J. Piekło, K. Hübner, Modelling the Production Process and Performance of Large Graphite Electrodes, in: The First International Conference on Advanced Materials Processing, Rotorua, New Zeeland, 2000.

[16] J. Piekło, K. Hübner, Dobór właściwości materiału złącza i elektrody celem optymalizacji wytrzymałości połączenia z wykorzystaniem modelowania numerycznego metodą elementów skończonych, Projekt celowy [Special project] nr 7784995 C/2496. 